\title{
Initial Teacher Certification Testing: Preservice Teachers' Experiences and Perceptions
}

\author{
Ruth A. Childs \\ Maura Ross \\ Andrew P. Jaciw
}

\begin{abstract}
Theintroduction of an initial teacher certification testin Ontarioin 2002was metby a wide range of responses from preservice teachers. This study, based on an A pril 2002 survey of 535 preservice teachers in a large initial teacher education program, describes the relationships among what the participants knew about theOntario Teacher Qualifying Test, their previous experiences with other large-scal e tests, and their beli efs about and attitudes toward the test.
\end{abstract}

Keywords: preservice teacher education, teacher certification, test preparation, factor analysis.

L'introduction d'un Testd'aptitudeà la profession enseignante en Ontario en 2002a suscité tout un éventail de réactions de la part des candidats à l'enseignement Cette étude, effectuée à la sui te d'un sondage menéen avril 2002 auprès de 535 candidats inscrits dans un vaste programme de formation à l'enseignement, décrit les liens entre ce que les participants connai ssai entdu Testd'aptitude à la profession enseignantedel'Ontario, leurs expériences antérieures avec d'autres tests à grande échelle etl eurs croyances et attitudes au sujetde ce testen particulier.

Mots dés : formation à l'enseignement, certification à titre d'ensei gnant, préparation en vue d'un test, analyse factorielle

In much of N orth A merica, candidates for teaching certificates must pass a certification testor tests. These tests vary in content-general pedagogy and/or subject-specific knowledge - and in format - paper-and-pencil tests, performance assessments, portfolio assessments, or some combination. Many of the tests have been controversial and much has been written about their history, passing criteria, and impact on preservice teachers and teacher education programs.

A nyone who has worked with preservice teachers in a jurisdiction

Canadian Journal of Education 27, 4(2002): 455-475 
with a certification test can attest that their responses to the prospect of taking such a test vary. Some seek out information about the test; others avoid discussing it. Some believe that such tests are well-constructed and fair; others are deeply skeptical. Some plan to prepare for the test; others believe that preparation is unnecessary. Some believe that poor performance on the test should have serious consequences; others do not. Some believe that teacher-education programs should explicitly hel $p$ them prepare for the test; others feel that individual preservice teachers should take responsibility for their own preparation.

Few studies have systematically explored preservice teachers' experiences and perceptions of certification tests (see, however, Bower, 2003 Portelli, Solomon, \& Mujawamariya, 2003). N one has examined the relationship between students' experiences and their perceptions. Specifically, how does preservice teachers' exposure to information about the test and their experiences with other large-scale assessments rel ate to their beliefs about and attitudes toward a certification test? This study explores these relationships for preservice teachers taking a new initial teacher certification test in Ontario (currently the only one in Canada). Understanding how preservice teachers vary in their knowl edge and beliefs about and attitudes toward the test and in their previous experiences with large-scale tests may help teacher-education programs plan test preparation activities. Understanding the relationships among their experiences and perceptions may suggest how to design activities for groups of preservice teachers.

\section{INITIAL TEACHER CERTIFICATION TESTING}

In 1871, Ontario introduced its first province-wide initial teacher certification test. Prior to 1871, most teachers had been certified by county boards, which issued county-speci fic teaching certificates based on widely varying standards. A few teachers, seeking certificates that would be valid province-wide, had attended the N ormal School in Toronto, the only formal teacher-education program at that time.

The 1871 test was administered over six days, with six hours of testing per day, and covered education theory and practice, and speci fic subjects such as al gebra, geography, and English grammar - content parallel to that of the N ormal School's final exams. By 1900 more teacher-education programs existed and most preservice teachers were certified based on their performance in those programs. In 1906 the provincial government abolished the boards responsible for the provincial tests. 
In 2001, Ontario began developing a new initial teacher certification test, the Ontario Teacher Qualifying Test; it was administered for the first time in A pril 2002 Beginning in 2003, preservice teachers had to successfully complete an accredited teacher-education program and pass the test to receive their teaching certi ficates. Unlike the 1871 test, the new test does not measure subject knowledge; instead, it measures general "professional knowledge" and "teaching practice" (Educational Testing Service, 2001). The test, four hours Iong, consists of multiple-choice questions and case studies accompanied by short answer questions.

Ontario is not al one in testing teachers prior to certification. Between 1977 and 1987, the number of U.S. states requiring candidates to write a licensure test increased from 3 to 44 (Porter, Youngs, \& Odden, 2001); in 199842 states induded at least one test as a certification requirement (National Research Council, 2001). Shanker (1996) attributes much of the increase in testing to concerns about the variation in teacher-education programs and the desire to set dear standards. Indeed, in 1987, the newly formed U.S. National Board for Professional Teaching Standards recommended that teacher certification requirements include testing of subject matter and pedagogical theory and practice, in a move toward implementing professional standards at education faculties across the country. Since the U.S. government created the "Teacher Quality Enhancements Grants for States and Partnerships" in 1998, teacher preparation programs with low passing rates on their state-mandated tests risk not being able to enroll students who receive federal financial aid.

Test format. Most tests in the 1970 s were multiple-choice. As Porter, Youngs, and Odden (2001) note in their review of the literature, some educators charged that multiple-choice questions about professional knowledge were often based on over-simplifications, so that "the greater a candidate's knowledge of how [classroom organization, teaching strategies, and instructional goals can affect] teaching, the more likely he or she was to have difficulty answering these questions" (p. 261). There is little evidence to ei ther support or disprove this assertion, however. Many of the recent tests ind ude other types of items. Some incorporate portfolio assessments, performance assessments, or case studies requiring written responses. For example, the Interstate $\mathrm{New}$ Teacher A ssessment and Support Consortium, created in 1987 by the Council of Chief State School Officers, the U.S. organization anal ogous to the Council of Ministers of Education Canada, is developing a performance assessment and written test for new teachers (Porter, Youngs, \& Odden, 2001). 
Test validity. Are initial teacher certification tests good measures of beginning teacher competence? Based on its review of the literature, the National Research Council (2001) conduded:

Little research has been conducted on the extent to which scores on current teacher licensure tests relate to other measures of beginning teacher competence. Much of the research thathas been conducted suffers from methodol ogical problems thatinterfere with making strong conclusi ons about the results. This makes ithard to determine what effect licensure tests mighthave on improving the actual competence of beginning teachers. ( $p$. 135)

Of particular concern in many jurisdictions is the possibility that different certification standards might result in better student performance. Strauss and Sawyer (1986) found, for school districts in N orth Carolina, that as a district's average teacher certification test scores increased, students' reading and math scores al so increased, and the failure rate on high-school competency tests decreased. The effects were very small, however, and itis und ear whether the higher teacher scores caused the improved student performance or teachers with higher scores were attracted to schools with higher performing students.

Goldhaber and Brewer (2000) used multiple regression to explore whether state certification standards had an impact on student learning. An analysis of data collected from grade- 12 public school students in mathematics and science, and from teachers of mathematics and science, most of whom were certified in subject areas, found that students who had teachers with mathematics degrees had higher mathematics test scores, al though the same was not found to be true in science. Teachers with doctoral degrees did not appear to further improve student test scores. Teachers with undergraduate degrees in education were found to have a negative impact on studentmathematics scores. The type of teacher certification (i.e., emergency or standard) did not affect student scores in mathematics and science.

Darling-Hammond (2000) examined the relationship of a state's percentage of teachers with full certification and a major in their field with student achievement on the National A ssessment of Educational Progress (NAEP). States with higher percentages of highly qualified teachers had significantly better student scores in reading and mathematics in both grades 4 and 8

The combination of high stakes for preservice teachers - and, increasingly, teacher-education programs - and scant validity evidence, particularly for tests of general pedagogical knowledge, notsubjectmatter 
knowledge, have caused initial teacher certification tests to be very controversial. Hess (2002), for example, describes a range of proposals, from calls for no certification to demands for additional certification criteria.

Test preparation. Whether preparing preservice teachers to take the testis the responsibility of the initial teacher education program, the teacher candidate, an organization such as the Ontario College of Teachers, or some combination is not dear. McD onough and Wolf (1987) reviewed U.S. case law and psychometric standards relevant to teacher testing and predicted:

In futurecaseslitigants may daim that they did nothave a fair opportunity to prepare for the test States may have tojustify teacher education programs that a state approved but that are not able to prepare students who can pass the tests. They may al so have to show that students were given adequate warning that the test was to be required. They may point to publication of study objectives and liberal reexamination policies as state efforts to honour test-takers' right of due process. (p. 211)

In McDonough and Wolf's view, teacher-education programs would be wise to consider helping preservice teachers prepare for the tests.

Even if teacher-education programs intend to prepare preservice teachers to take the tests, doing so can prove difficult Information about the test's content is often not readily available. For example, Zigo and Moore (2002) describe how they coped, as teacher educators, with thelack of information available about one of the Praxis tests, a required step in the initial certification process in Georgia. A fter reviewing materials available from the test publisher in printed copy and on its website, Zigo and Moore began to ask their students about the test They report that this strategy was not very successful for three reasons: (a) different forms of the test were used, (b) students' recollections were inconsistent, and (c) students' recollections seemed to depend on their perceptions of personal weaknesses in the content the test was measuring.

Zigo and Moore (2002) subsequently took the test themselves. They are not alone in resorting to this strategy to find out what the preservice teachers are facing (see, for example, Bowen, 2002 Luna, Sol sken, \& Kut, 2000 ). They found that some of the items were based on theories that were inconsistent with their understanding of established professional standards. Furthermore, they felt that the use of a multiple-choice item format made the test confusing. Zigo and Moore incorporated what they learned from taking the test into their program by providing students with a variety of test preparation activities, such as information sessions, direct instruction, and test review. 
Bowen (2002) writes of her experience attending a Praxis II test of English. She was motivated by her awareness, as an English professor and associate dean, that teacher-education programs are not al ways successful at preparing students for certification exams. Bowen observes that preservice teachers continue to rely on teacher education programs to provide them with subject-specific knowledge in addition to pedagogical knowledge and skills. She suggests that English departments, regardless of their philosophical position on testing, should take active roles in preparing students for certification examinations, something she believes would benefit teacher-education programs, teacher educators, and preservice teachers.

Luna et al. (2000) describe the difficulty educators may face when preparing preservice teachers to take a test that is based on an opposing pedagogical approach. For them, the Communication and Literacy Skills (CLS) section of the Massachusetts Educator Certification Tests presented such a quandary. Luna et al. devel oped a three-part activity for "situating, unpacking and critiquing" high stakes tests. The "unpacking" part of their workshop provided students with a structured set of questions designed to provide an understanding of the form, purpose, process, and evaluation of literacy practices. The students were then encouraged to "critique" the CLS using the same questions, "making the norms and expectations of the CLS testing situation explicit" (Luna et al., 2000 p. 282). The preservice teachers who examined the CLS testitems and scoring criteria commented on the dosed nature of the scoring even in the short answer response items, and were able to identify a "pre-specified format" which left test takers with little autonomy in their responses. Luna et al. reported that preservice teachers who understood the nature of the CLS test were more likely to pass by using their knowledge and skills to break down complex subject matter to structure answers to discrete questions.

Delandshere and A rens (2001) explored the effects of certification standards on teacher-education programs in two states chosen for their different approaches. A fter reviewing numerous documents and interviewing 41 teacher educators, the authors concluded that each of the programs was being aligned with the certification standards and test specifications. Participants who did not incorporate the standards into their assessment practices were identified during the accreditation process, and received poor evaluations. Clearly, the pressure for initial teachereducation programs to prepare preservice teachers to take certification tests rai ses difficul tissues aboutprograms' autonomy and responsibilities.

Impacts on preservice teachers. As the preceding section suggests, initial teacher certification tests can affect the preparation preservice teachers 
receive. In addition, individual preservice teachers must pass the test or tests to receive their teaching certificates. This may be more difficult for some preservice teachers than for others. Numerous studies have focused on the pass rates of subgroups of preservice teachers by race or ethnicity. A study by the NRC (2001), for example, obtained data for 12states from the Praxis II: Principles of Learning and Teaching (PLT) test for 1998/1999 Analyzing the passing rates by racial/ethnic group, the NRC found that the average passing rates ranged from $48 \%$ for A frican A merican preservice teachers and $65 \%$ for Hispanic Americans, to $82 \%$ for A sian Americans, and $86 \%$ for those who reported their race as Whi te. It is important to note that, al though the same test is used in these states, each state sets its own passing score; the NRC applied each state's passing score to its preservice teachers. The NRC report also summarizes work by other researchers who worry that pedagogical knowledge tests, such as the Praxis II: PLT, may be particularly susceptible to bias against non-majority groups: "I tems or expected responses that overgeneralize notions about effective teaching behaviors to contexts in which they are less valid may unfairly disadvantage minority candidates who are more likely to live and work in these settings" (pp. 110-111).

Latham, Gitomer, and Ziomek (1999) discuss ongoing concerns with the lack of gender and ethnic diversity among preservice teachers, and the problems that could emerge as a result of placing further certification demands on an al ready stressed profession. They examined the SAT scores of students who had passed the Praxis II and found they had higher academic skills than the general population. One exception was preservice teachers seeking the elementary education licence, who were found to have scores "substantially lower than ... those seeking licensure in spedi fic content areas" (Latham, Gitomer, \& Ziomek, 1999 p. 25).

Impactson initial teacher education programs. Oneimpacton teacher education programs has al ready been discussed: the pressure to align curricula with a test's content The threat of losing funding if preservice teachers do not perform well on the test may motivate other changes. For example, Flippo and Riccards (2000) studied the effects of the controversial Massachusetts Educator Certification Tests on teachers and on teacher-education programs. During the firstyear of the tests, $59 \%$ of the preservice teachers failed, with the result that only six of the 55 state-certified, teachereducation programs received accreditation. Massachusetts' Department of Education was forced to set a three-year implementation period to provide time for teacher-education programs to meet the demands of the test. Teacher-education programs in Massachusetts have since implemented entrance exams to screen preservice teachers, and aligned 
curricula to ind ude direct teaching to the test, both steps that Flippo and Riccards (2000) fear may further reduce the diversity of teachers entering the profession. The negative press rel eases surrounding the admini stration of the test were also expected to further dissuade prospective teachers from entering the profession.

\section{THIS STUDY}

To understand the relationships among what preservice teachers know about an initial teacher certification test, their pastexperiences with testing, and their current beliefs and attitudes, we surveyed preservice teachers preparing to take a new licensure test. The questions of interest were: What are preservice teachers' experiences and perceptions of an initial teacher certification test? and How do their experiences relate to their perceptions?

\section{METHOD}

\section{Subjects}

In A pril 2002, two weeks before the Ontario Teacher Qualifying Test (OTQT) was administered for the first time, several hundred preservice teachers at the Ontario Institute for Studies in Education of the University of Toronto (OISENT) participated in faculty-supported workshops about the test An exact count of those who attended the workshops, unfortunately, is not available. Estimates, based on the capacity of the auditorium in which the sessions were held, place the total number at about 600 Of those attending, 552 returned a questionnaire. Seventeen questionnaires were more than $50 \%$ blank and so were dropped from the dataset, leaving 535 questionnaires for analysis. Of the remaining questionnaires, $72 \%$ ind uded no omitted questions and 93\% omitted two or fewer questions. In the 2001/ 2002 academic year, 1,190preservice teachers were enrolled in OISENT's Primary/Junior, Junior/ntermediate, and Intermediate/Senior programs. (Candidates for technical studies degrees or diplomas were not required to take the OTQT, so are notind uded in this count) The 535questionnaires, therefore, represent $45 \%$ of the preservice teachers in OISENT's programs to which the test applied.

Because the workshops were voluntary, the respondents cannot be considered a random sample from the studentbody. However, theindusi on of demographic questions permits comparisons of the respondents to all preservice teachers at OISENT. Seventy-eightpercent of respondents were 
female. This is similar to the $76 \%$ in the OISENT program. Thirty-three percent of respondents were from the Primary/Junior program, 15percent from the Junior $/$ ntermediate program, and just over 50 percent from the Intermediate/Senior program (a few respondents did not provide program information). These percentages are similar to those for all preservice teachers: $29 \%, 16 \%$, and $54 \%$.

Instrument

The questionnaire was developed specifically for use as part of the workshops. I tems were created based on (a) feedback from earlier workshops with smaller groups of preservice teachers, (b) an examination of e-mail messages in an on-line forum about teacher testing, and (c) the themes thatemerged from theliterature revi ew. Items addressed preservice teachers' exposure to the OTQT, past experiences with large-scale assessments, and perceptions of the OTQT. The exposure and experience items had response options of "yes," "no," and, for some items, "not sure" or "somewhat" Response options for the perception i tems were "strongly disagree," "disagree," "agree," "strongly agree," and "don'tknow."

Descriptive Statistics

The percentages of preservice teachers responding positively to experience questions were computed. In addition, the percentages of preservice teachers disagreeing (i.e., selecting "disagree" or "strongly disagree"), agreeing (i.e., sel ecting "agree" or " strongly agree" ), and responding "don't know" for each perception item were computed.

Factor Analysis

To identify patterns of responses, the perception items were subjected to a factor analysis. In preparation for the factor analysis, the response options were coded 1 to 5 for "strongly disagree," "disagree," "don'tknow," "agree," and "strongly agree," respectively. "Don't know" was included as the middle point on the scal e for the factor analyses to maximize the number of analyzable responses. Because even this recoding yields only five response options, polychoric correlations, rather than Pearson productmomentcorrelations, werecomputed (for items with few response options, Pearson product-moment correlations tend to be underestimates; see Mislevy, 1986). Maximum likelihood extraction and promax rotation were used. Both the convention of keeping only those factors that have 
eigenvalues greater than one and examination of the scree pl ot suggested five factors. A few items that did notload on any of the factors or loaded on two or more were dropped from the analyses.

\section{RESULTS AND DISCUSSION}

Experiences

Preservice teachers' exposure to information about the OTQT is summarized in Table 1. Almost all (94.4\%) of the respondents reported having been in a dass or workshop in which the test was discussed. However, fewer had actually seen the publidy available information. Although $44.1 \%$ had read the test specifications and $63.4 \%$ had read the available example case studies or had seen case studies through participating in the pilot or field test for the OTQT, only $34.8 \%$ had seen both and $267 \%$ had seen neither. Only half (505\%) reported having actively sought primary information about the test; that is, having visited the websi tes of the organizations that created the test (the Ontario Principal s' Council [OPC], in coll aboration with the Educational Testing Service [ETS]) or of the test's sponsor (the Ontario Ministry of Education [OMOE]). In fact, $17.2 \%$ reported having seen none of these - specifications, cases, or websites.

TABle 1

PreserviceTeachers' Experienœes

Percentage

Exposuretolnformation About theOTQT

Experienced dass discussions or workshops about the test

$94.4 \%$

Read the test specifications

$44.1 \%$

Read example and/or draft cases

$63.4 \%$

Visited the Ontario Principals' Council and/or Ontario Ministry of Education websi tes for information about the test $\quad 505 \%$

Past Test-Taking Experience

Had taken a standardized test (e.g., SAT, GRE, LSAT, GMAT, MCAT) since high school 
The test specifications were first made avail able to OISENT students in November 2001, when they were posted in electronic form on an intranet discussion group labeled "Teacher Testing Forum." They were distributed in paper form in February 2002 at a panel discussion organized by the OISENT Student Teachers' U nion. The example case studies were posted on the OPC's website by February 2002 They were also distributed by some OISENT instructors in their dasses.

The Internet was an important source of information about the test. Both OPC and ETSposted OTQT information on their websites. The OMOE posted press releases and other information about the test.

In addition to discussions that took place within regular classes, a number of OTQT workshops, forums, and discussions were held at OISE/ UT to address student and faculty concerns. The dean's office held five policy forums between October 2001 and March 2002 The Student Teachers' Union sponsored a panel discussion in February and a demonstration in front of the provincial legislature building in March 2002

A s Table 1 al so reports, only $14.2 \%$ of preservice teachers reported having taken a standardized test, such as the SAT, the Graduate Record Examination, or similar tests, since high school. Since the late 1960s, entrance to universities in Ontario has been based on marks, rather than on admissions tests. I tis likely that only individuals who graduated from high school outside Canada or considered attending school elsewhere would have experience with such tests.

Perceptions

Factor Analysis. The analysis of the perception i tems yielded five factors. Table 2 presents the correlations of the individual statements with the factors, corrected for the correlations among the factors. Table 3 presents the correlations among the factors.

A $n$ examination of the statements loading on each factor suggests that the first factor concerns the U tility of the test, the second factor concerns Preparation by preservice teachers to take the test, the third factor concerns the possibility of having Other Tests as well as or instead of the OTQT, the fourth factor concerns the Consequences of the test for preservice teachers, and the fifth factor concerns the Emphasis placed on the test by the Ontario Ministry of Education, the initial teacher-education program, and the media. The items loading on each factor will be discussed in detail below.

Some of the factors are moderately correlated. As Table 3 shows, the Other Tests and Consequences factors are correlated .388 Both of these factors are correlated with the U tility factor, .345 and .391 , respectively, 


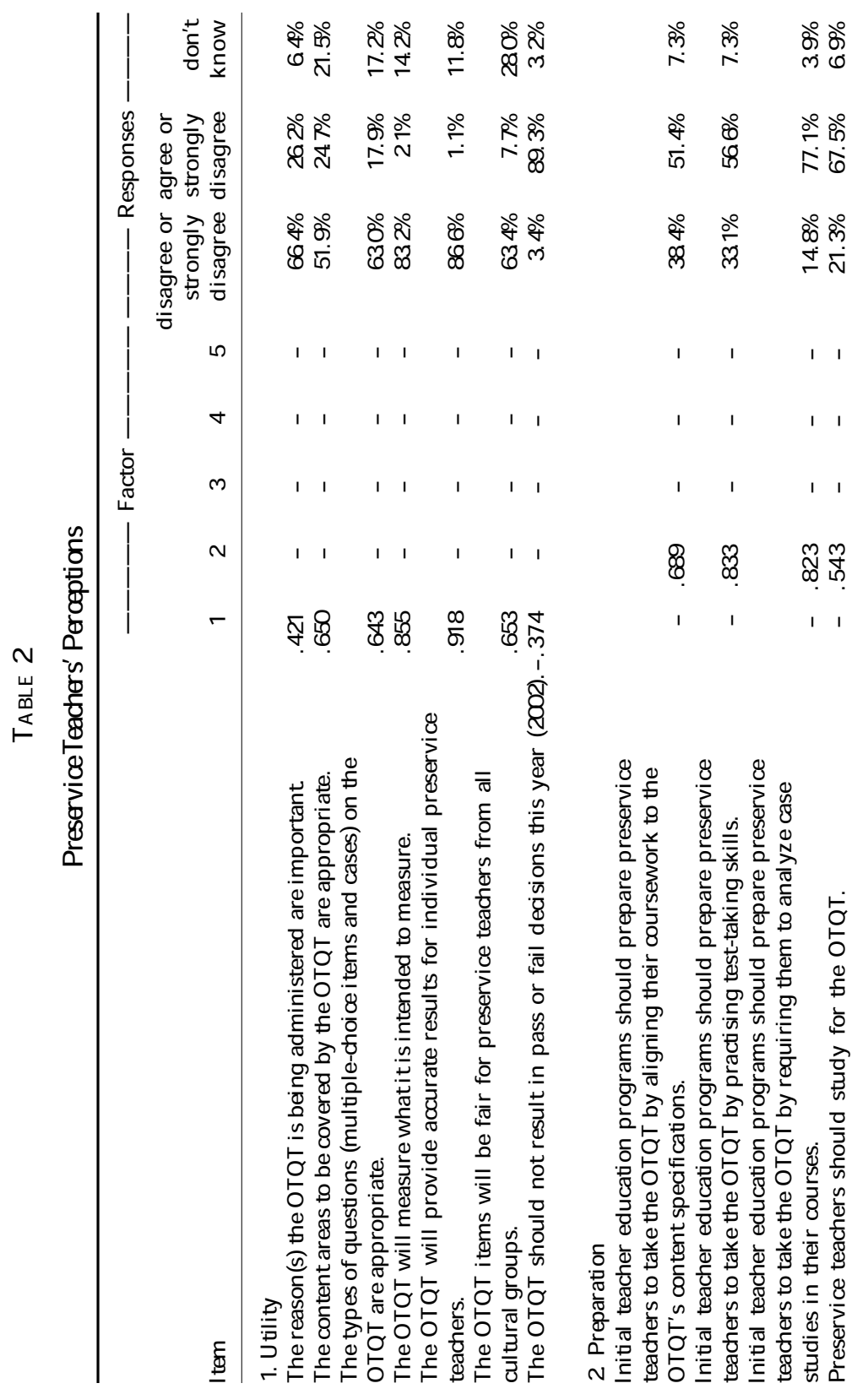




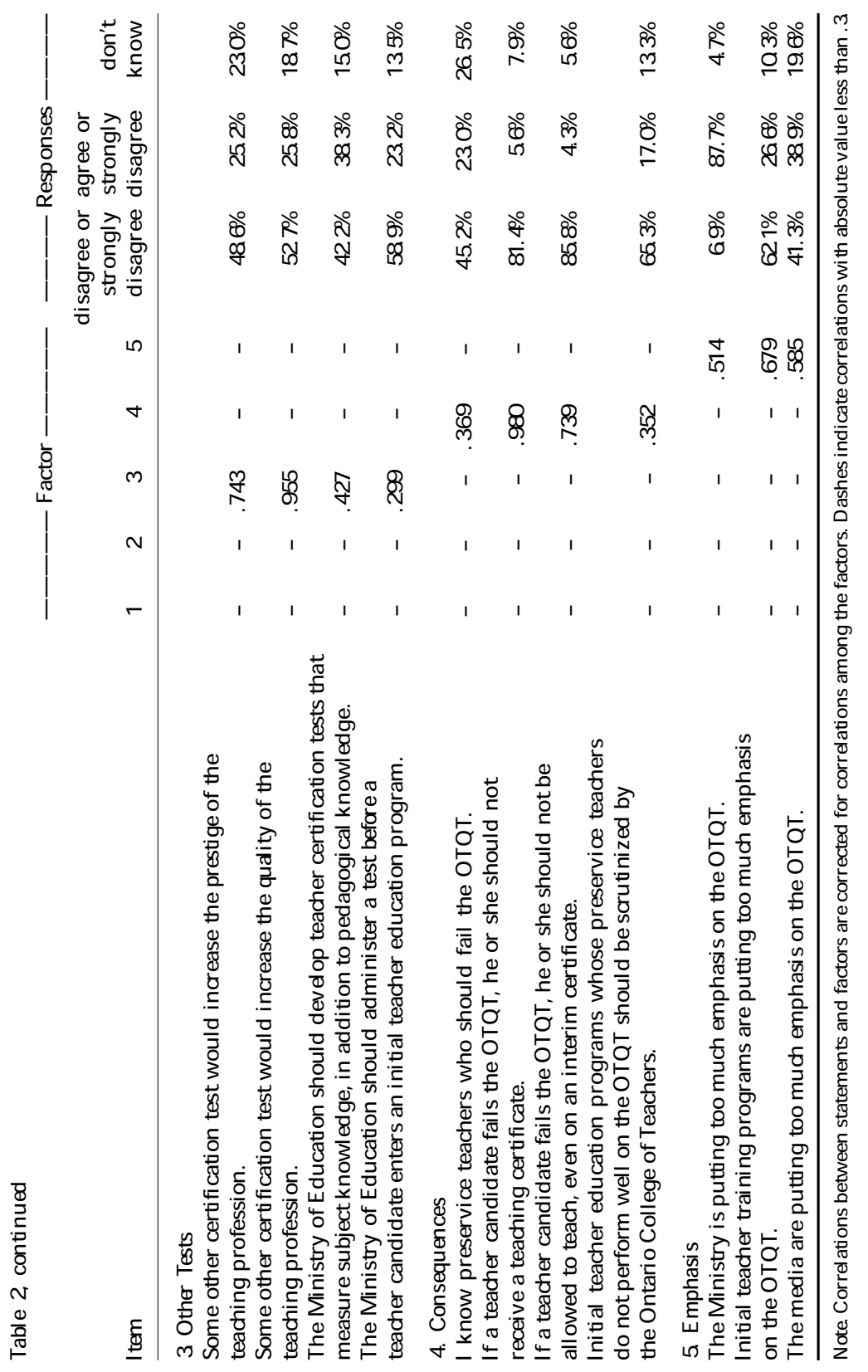


TABLE 3

Correlations Among Factors

\begin{tabular}{lrccc}
\hline & \multicolumn{4}{c}{ Factor } \\
\cline { 2 - 5 } \multicolumn{1}{l}{ Factor } & 1. Utility & 2 Preparation & 3. Other Tests 4. Consequences \\
\hline 2 Preparation & .141 & & & \\
3. Other Tests & .346 & .176 & .368 & -.256 \\
4. Consequences & .390 & .094 & -.189 & -.098 \\
5. Emphasis & -.045 & -.098 & \\
\hline
\end{tabular}

indicating that preservice teachers who held more positive beliefs about the utility of the test also tended to support the creation of additional tests and the assignment of consequences based on this test. The Preparation factor is the least correlated with the other factors, suggesting that preservice teachers' beliefs about appropriate test preparation activities and who should be responsible for test preparation were not related to their beliefs about the utility of the test and its appropriateness. The Emphasis factor is slightly negatively correlated with the other factors. The correlation between Emphasis and Consequences, for example, is -.256 meaning that preservice teachers who felt the test should not have serious consequences also tended to feel that it was receiving too much emphasis - and vice versa.

Items on theUtility Factor. Table 2al so reports the percentages of preservice teachers disagreeing, agreeing, and selecting "don't know" for each of the items. Two thirds (66 4\%) of preservice teachers disagreed that the reasons the OTQT was being administered wereimportant. When asked about the content of the test and the types of questions, $51.9 \%$ disagreed that the content was appropriate and $630 \%$ disagreed that the types of questions were appropriate. However, $21.5 \%$ and $17.2 \%$ of preservice teachers responded "don't know" to these items. Many of these responses may have been the resul t of lack of exposure to information about the test.

Most respondents (83.2\%) di sagreed with the suggestion that the OTQT will measure whatitis intended to measure. Because detailed information about the OTQT was difficult to find in the months preceding its first administration, preservice teachers and instructors were left to speculate aboutmany of those details, from the purpose of the test to the difficul ty of the items and likely pass scores. Responses to this item likely reflect the skepticism this speculation encouraged.

When queried about whether the OTQT would provide accurate resul ts, even more $-866 \%$ - disagreed, and only $1.1 \%$ agreed. Although the 
design of the questionnai re makes exploring the reasons behind this strong belief impossible, it helps to explain the preservice teachers' high anxiety levels, and suggests some directions for future research. Itis interesting to note that, in response to the item about the OTQT's fai rness across cul tural groups, al though a relatively lower percentage of respondents disagreed or strongly disagreed (634\%), 28\% selected "don't know," responses once again demonstrated a lack of darity about the test.

In response to the assertion that the OTQT should not result in pass or fail decisions this year, $89.3 \%$ agreed. When one traces the chronology of events surrounding the OTQT's implementation, it is easy to understand this reaction. Although the first mention of the OTQT was in A pril 1999, piloting only began in September 2001 . This late development led to much speculation about whether the test would take place for $2001 / 2002$ preservice teachers, and the legality of its resul ts if in factit did take place.

Items on thePreparation Factor. Despite the respondents' negative attitudes towards the OTQT, two thirds (67.5\%) agreed with the suggestion that preservice teachers should study for the test. This is perhaps notsurprising because the respondents were attending an information session on the purpose and content of the OTQT.

Participants' responses to the assertion that initial teacher-education programs should align their curricula to the test were split, with $51.4 \%$ agreeing and $384 \%$ disagreeing. When asked whether programs should teach test-taking skills, the majority of respondents agreed (56\%). An even higher percentage of the participants (77.1\%) agreed that teachereducation programs should include analyzing case studies in the curriculum.

Items on the Other Tests Factor. A bout a quarter (25.2\%) of respondents believed that some other certification test would increase the prestige of the teaching profession. When asked whether some other certi fication test would increase the quality of the teaching profession, $25.8 \%$ agreed. Although these percentages are almostidentical, they do not represent the same students - only $16 \%$ agreed with both statements.

An examination of the Ministry's role in the testing process reveal ed al most an even split between respondents who disagreed with the development of certi fication tests that measure subjectknowledge (42 2\%), and those who agreed (383\%). A higher number opposed the suggestion that the Ministry administer a test before a teacher candidate enters an initial teacher-education program (589\%). In other jurisdictions, the introduction of an entrance examination has raised pass rates on the certification tests by screening out at the earlier step candidates likely to fail the certification test. The result for preservice teachers is thatitis more 
difficul to get into a program, but once they are in one, their probability of receiving certification is improved.

Items on theConsequences Factor. Preservice teachers expressed the greatest uncertainty about the statement, "I know preservice teachers who should fail the test," with $265 \%$ selecting "don't know." Almost half (45.2\%) disagreed and only $230 \%$ agreed. This hesitance to comment on other preservice teachers' ability may have been due to concerns about professionalism. In addition, most preservice teachers had not observed their peers teaching, and so may have fel t they had inad equateinformation on which to make such a judgment.

Only $56 \%$ of the respondents agreed that preservice teachers who failed the test should not receive a teaching certificate. A pproximately the same number $(4.3 \%)$ agreed that preservice teachers who fail the test should not be allowed to teach, even on an interim certificate. This response is not surprising, because those students who question the validity of the OTQT, using it to bar preservice teachers from teaching would be illogical.

A Imost two thirds (65.3\%) of the respondents disagreed that teachereducation programs whose preservice teachers do poorly should be scrutinized by the Ontario College of Teachers, the professional body responsible for accrediting programs.

Items on theEmphasis Factor. When asked whether the Ministry was putting too much emphasis on the OTQT, $87.7 \%$ agreed. Regarding whether initial teacher training programs are putting too much emphasis on the OTQT, however, only $266 \%$ agreed and $621 \%$ di sagreed. These results are difficult to interpret because participants who disagreed could be advocating less emphasis or could believe that the emphasis is al ready "just right." Unfortunately, the wording of the question does notall low us to distinguish between these possibilities. A bout whether the media was putting too much emphasis on the OTQT, respondents were almost evenly split, with $389 \%$ agreeing and $41.3 \%$ disagreeing. Al most $20 \%(19.6 \%)$ responded that they "don't know."

The Relationships Between Experiences and Perceptions

Exposure to information about the test did have an impact on some attitudes. Notably, those preservice teachers who had read the test specifications were si gni ficantly more likely to agree that the contentareas to be covered by the test are appropriate $\left(352 \%\right.$ vs. $168 \%, \chi^{2}(1)=977, p<$ .01). In addition, only $9.9 \%$ of those who had read the specifications responded "don't know" to that statement, compared with $31.7 \%$ of those who had not read the specifications. 
Preservice teachers who had read example or pilot or field test case studies were al so significantly morelikely to agree that the content areas to be covered by the testare appropriate $\left(294 \%\right.$ vs. $\left.17.7 \%, \chi^{2}(1)=7.86, p<.01\right)$. The percentages responding "don'tknow" to thi s item were similar: $20.4 \%$ and $24.5 \%$. Interestingly, the preservice teachers who had seen cases were significantly less likely to agree that the Ontario Ministry of Education should devel op subject area tests (37.0\% vs. $\left.45.6 \%, \chi^{2}(1)=7.09, p<.01\right)$.

Because al most all preservice teachers had been exposed to an in-dass discussion or workshop about the OTQT, it was not useful to compare those few who had not with those who had.

Visiting the OPC and/or OMOE websites for information about the OTQT required some effort by the preservice teachers, so doing so suggests a higher level of interest in the test. Perhaps it is not surprising, then, that significantly fewer of those who had visited the websites agreed that the media was putting too much emphasi s on the OTQT (34.1\% vs. $439 \%, \chi^{2}(1)$ $=1093, \mathrm{p}<.001$ ). However, these preservice teachers' responses did not differ significantly on any other statements.

Even though fewer than $15 \%$ of the preservice teachers had taken a standardized test since high school, those who had thatexperience differed significantly in their responses to several items from those who did not In particular, those with test-taking experience were significantly less likely to agree with "I know preservice teachers who should fail the OTQT" $\left(15.1 \%\right.$ vs. $\left.260 \%, \chi^{2}(1)=592, p<.05\right)$, more likely to agree that a teacher candidate who fails that OTQT should notbe all owed to teach, even on an interim certificate $\left(9.7 \%\right.$ vs. $\left.3.7 \%, \chi^{2}(1)=506 p<.05\right)$, more likely to agree that teacher-education programs whose preservice teachers did poorly should be scrutinized $\left(29.2 \%\right.$ vs. $\left.16 \%, \chi^{2}(1)=4.64, p<.05\right)$, and less likely to agree that the test should not result in a pass/fail decision $(85.5 \% \mathrm{vs}$. $\left.94.7 \%, \chi^{2}(1)=6.23 p<.05\right)$. Although these differences are not highly significant, given thelarge number of comparisons being conducted, they are suggestive of differences in perception. In particular, those with personal test-taking experience were more likely to accept that the OTQT should have consequences for preservice teachers and teacher-education programs.

\section{CONCLUSION}

Although the preservice teachers appeared to agree in principle with testing, they were hesitant to acceptits application as the final step in the teacher certification process, primarily due to concerns about its purpose, content, and form. However, the preservice teachers varied widely in their 
perceptions of the test. Their exposure to information about the test and previous experience with large-scale testing appeared to affect their perceptions. In particular, students who had seen example test items and test specifications were more likely to agree that the content of the test was appropriate than those who had not This speaks well for the test's face validity, butunderlines the importance of exposing preservice teachers to these materials. Those who had previously taken high-stakes, largescale tests were morelikely to accept the proposed consequences of the test than those who had not.

Implications

Initial teacher-education programs are increasingly under pressure to prepare preservice teachers to take certification tests. Although the consequences for Ontario programs are not yet clear, the pass rates by program are expected to be published. Whether publication of the resul ts al one will pressure teacher education programs to engage in formal test preparation activities or even to align their curricul a with the test content remains to be seen. Whether additional pressures will be brought to bear by the Ontario College of Teachers when programs are re-accredited is al so as yet unknown.

Programs may resist defining their curricula based on a test's spedi fications. If the current curricula are based on careful judgments about what beginning teachers need to know and be able to do, to change the curricula would require compromising those judgments and, possibly, signal a willingness to make even more changes. However, other approaches to preparing preservice teachers to take a certification test are al so possible. Luna et al.'s (2000) use of a test's content to teach critical thinking about educational theories and analysis of the test developers' expectations was described earlier. Discussing the content that will be on the test, familiarizing the students with the test's format, and teaching test-taking strategies do require time, but not a realignment of curricula, and can go far in all aying preservice teachers' worries about the test Indeed, more than half of the preservice teachers surveyed in this study believed that their program should prepare them for the test That is not to say that they believe all the responsibility lies with the teacher-education program: Most also believed that preservice teachers should study on their own. Furthermore, their perceptions of appropriate test preparation activities and who should be responsible for test preparation were not related to their beliefs about the utility of the test and its appropriateness.

The results of this study suggest that most preservice teachers were 
skeptical about the new test However, those with more information about the test tended to beless skeptical. Further, those with previous experience taking a large-scale, high-stakes test were more accepting of the test. Although the survey did not ask directly how stressful the preservice teachers found preparing for the test, our assumption is that perceptions that the test is unfair and inappropriate result in increased stress. As teacher-education programs consider whether and how to prepare their students for these tests, the stress preservice teachers may experience due simply to lack of knowledge about the tests is important to bear in mind.

Limitations

This study has a number of limitations. The preservice teachers who completed the questionnaire were from a single initial teacher-education program, al beit the largestin Ontario. In addition, they were nota random sample of the preservice teachers studying in that program. The extent to which they are representative of preservice teachers in the particular program, and across the province, is difficult to judge, al though the distributions by gender and panel are typical.

The survey was conducted during the firstyear of the testing program. Follow-up studies are needed to determine whether exposure to information about the test and perceptions of the test change as the testing program matures and the stakeholders become more accustomed to it.

Finally, this study relies on preservice teachers' reporting of their experiences and perceptions. The questions about experiences, in particular, may not have been interpreted in the same way by all respondents. For example, Bower (2003), in a study of teacher educators and preservice teachers preparing for the OTQT, found that the preservice teachers' and teacher educators' perceptions of the same test preparation activities did not al ways agree.

FutureDirections

Although over $90 \%$ of the students reported discussing the OTQT in their teacher-education courses, the content and extent of these discussions were not explored. A study of test preparation activities across and within teacher-education programs would help educators understand the variation in activities. In addition, a comparison between the test specifications and the initial teacher-education programs' curricula would provide valuable information both about the preservice teachers' opportunity to learn the material to be tested and about the possible 
impact of the test on the programs.

Preservice teachers' anxiety about teacher certification testing and the determinants of that anxi ety are not well understood. If teacher education programs are to prepare preservice teachers to take certification tests, they will likely be more effective if they are able to identify and address the determinants.

This study suggests that previous test-taking experience affects perceptions of teacher certification tests. For those preservice teachers who do not have any similar experiences, would providing practice opportunities in an environment similar to what they will face in the actual licensure test be hel pful?

We expect the results of this study and of such future research to be of interest beyond Ontario, as other provinces and states search for ways to address initial teacher certification testing in teacher-preparation programs. As we better understand how the preservice teachers experience preparation for such tests, and how they perceive the experience, we will gain a valuable perspective on the implications of certification testing both for preservice teachers and for initial teacher-education programs.

\section{A CKN OWLEDGEMENTS}

Thanks to Barbara Bower, Janice Owens, and Monica Paabo for assistance in collecting and analyzing the data for this study, and to Carol Rolheiser and Lyn Shulha for suggestions about how best to present the findings. This artide is based on a paper presented at the annual meeting of the Canadian Society for the Study of Education, Halifax, NS, May 2003

\section{REFERENCES}

Bowen, B. A. (2002). Teacher testing: Advice for faculty in literature, rhetoric, and creative writing. English Education, 34, 127-136

Bower, B. (2003). Preparing for the first Ontario Teacher Qualifying Test: Experiences of pre-service teachers and teacher educators at the Ontario Institute for Studies in Education of the University of Toronto. Unpublished master's thesis, Ontario Institute for Studies in Education of the University of Toronto.

Darling-H ammond, L. (2000). Teacher quality and student achievement Education Policy Analysis Archives, 8(1). Retrieved March 17, 2004, from http:// epaa.asu.edu/epaa $N$ \&n 1

Delandshere, G., \& A rens, S. A. (2001). Representations of teaching and standards-based reform: A re we dosing the debate about teacher education. Teaching and Teacher Education, 17, 547-566 
Educational Testing Service. (2001, October). Final specifications for the Ontario Teacher Qualifying Test. Princeton, $N \mathrm{~J}$ : Author.

Flippo, R. F., \& Riccards, M. P. (2000). Initial teacher certification testing in Massachusetts: A case of the tail wagging the dog. Phi D dta Kappan, 82, 34-37.

Goldhaber, D. D., \& Brewer, D. J. (2000). Does teacher certification matter? High school teacher certification status and student achievement. Educational Evaluation and Policy Analysis, 22, 129-145

Hess, F. M. (2002). A modest proposal: The case for radically overhauling teacher license. American School Board Journal, 189(4), 28-29.

Latham, A. S., Gitomer, D., \& Ziomek, R. (1999). What the tests tell us about new teachers. Educational Leadership, 56(8), 23-26

Luna, C., Solsken, J., \& Kut, E. (2000). Defining literacy: Lessons from highstakes teacher testing. Journal of Teacher Education, 51, 276-288

McDonough, M., \& Wolf, W. C. (1987). Testing teachers: Legal and psychometric considerations. Educational Policy, 1, 199-213.

Mislevy, R. J. (1986). Recent developments in the factor analysis of categorical variables. Journal of Educational Statistics, 11, 3-31.

National Research Council. (2001). Testing pre-service teachers: The role of licensure tests in improving teacher quality. Committee on A ssessment and Teacher Quality, Board on Testing and A ssessment. Washington, DC: N ational A cademy Press.

Portelli, J. P., Solomon, R. P., \& Mujawamariya, D. (2003). A critical analysis of the Ontario Teacher Qualifying Test: Pre-service teachers' perspectives (preliminary research report). Unpublished manuscript. Retrieved March 5 , 2003 from http://home.oise.utoronto.ca/\% TEjportelli/OTQT_report.pdf

Porter, A. C., Youngs, P., \& Odden, A. (2001). Advances in teacher assessments and their uses. In V. Richardson (Ed.), Handbook of research on teaching (4th ed.) (pp. 259-297). Washington, DC: A merican Educational Research A ssociation.

Shanker, A. (1996). Quality assurance: What must be done to strengthen the teaching profession. Phi Detta Kappan, 78 220-224.

Strauss, R. P., \& Sawyer, E. A. (1986). Some new evidence on teacher and school competencies. Economics of Education Review, 5, 41-48

Zigo, D., \& Moore, M. T. (2002). A ccountability and teacher education: Just like everyone else - Teaching to the test? English Education, 34, 137-155. 